\title{
Minireview
}

\section{Adrenomedullin and tumour angiogenesis}

\author{
LL Nikitenko*, I,3, SB Fox², S Kehoe', MCP Rees' and R Bicknell ${ }^{3,4}$ \\ 'Nuffield Department of Obstetrics and Gynaecology, The University of Oxford, John Radcliffe Hospital, Oxford, OX3 9DU, United Kingdom; \\ ${ }^{2}$ Nuffield Department of Clinical Laboratory Sciences, The University of Oxford, John Radcliffe Hospital, Oxford, OX3 9DU, United Kingdom; \\ ${ }^{3}$ Molecular Angiogenesis Laboratory, Cancer Research UK, Weatherall Institute of Molecular Medicine, The University of Oxford, John Radcliffe Hospital, \\ Oxford, OX3 9DU, United Kingdom; ${ }^{4}$ Institute for Biomedical Research, Birmingham University Medical School, Edgbaston, Birmingham B I 5 2TT, \\ United Kingdom
}

\begin{abstract}
The angiogenic activity of peptide adrenomedullin (AM) was first shown in 1998 . Since then, a number of reports have confirmed the ability of AM to induce the growth and migration of isolated vascular endothelial and smooth muscle cells in vitro and to promote angiogenesis in xenografted tumours in vivo. In addition, knockout murine models point to an essential role for AM in embryonic vasculogenesis and ischaemic revascularisation. AM expression is upregulated by hypoxia (a typical feature of solid tumours) and a potential role as a regulator of carcinogenesis and tumour progression has been proposed based on studies in vitro and in animal models. Nevertheless, translational research on AM, and in particular, confirmation of its importance in the vascularisation of human tumours has lagged behind. In this commentary, we review current progress and potential directions for future research into the role of $A M$ in tumour angiogenesis.
\end{abstract}

British Journal of Cancer (2006) 94, I-7. doi:10.1038/sj.bjc.6602832 www.bjcancer.com

Published online 25 October 2005

(c) 2006 Cancer Research UK

Keywords: adrenomedullin; CRLR; CL; angiogenesis; tumour; endothelial cell

The increased risk of endometrial polyps, hyperplasia and cancer in women receiving tamoxifen treatment for breast cancer prompted our group to look for genes induced in endometrial isolates by tamoxifen, but not oestrogen. PCR differential display identified the vasoactive peptide adrenomedullin (AM) as one such gene (Zhao et al, 1998). We subsequently showed AM to be an endothelial cell growth factor, having potent in vivo angiogenic activity and promoting tumour growth in animal models (Zhao et al, 1998; Nikitenko et al, 2000; Oehler et al, 2001, 2002). The last 7 years have seen increasing interest in elucidating a role of AM in tumorigenesis. The purpose of this commentary is to review those studies and to identify current unanswered questions.

\section{ADRENOMEDULLIN}

\section{Adrenomedullin peptide}

Andrenomedullin is a 52 -amino-acid peptide originally isolated from a human phaeochromocytoma (Kitamura et al, 1993a). It is produced through cleavage of a 185-amino-acid prohormone (pre-proadrenomedullin), which also yields proadrenomedullin $\mathrm{N}$-terminal 20 peptide (PAMP). Andrenomedullin belongs to the calcitonin gene peptide superfamily based on its homology with calcitonin gene-related peptide (CGRP) and amylin (Poyner et al,

\footnotetext{
*Correspondence: LL Nikitenko;

E-mail: leonid.nikitenko@obs-gyn.ox.ac.uk

Received 8 August 2005; revised 30 August 2005; accepted 23 September 2005; published online 25 October 2005
}

2002). The pleiotropic activities of AM were recognised within a few years of its initial characterisation as a vasodilatory peptide (Kitamura et al, 1993a; reviewed by Hinson et al, 2000). The expression and secretion of AM has been demonstrated in many tumours and biological fluids and it has been implicated in the modulation of numerous physiological processes (reviewed in Hinson et al, 2000). For example: (1) it is a growth factor (Hinson et al, 2000), (2) it is angiogenic in in vitro models and in vivo, (Zhao et al, 1998; Nikitenko et al, 2000; Kim et al, 2003), (3) it inhibits apoptosis in endothelium and isolated tumour cells (Kato et al, 1997; Martinez et al, 2002; Oehler et al, 2002), (4) it is a potent vasodilator (reviewed by Hinson et al, 2000), (5) it regulates endothelial permeability (Hippenstiel et al, 2002), and (6) it contributes to adhesion and differentiation of bone marrowderived mononuclear cells into endothelial progenitor cells (Iwase et al, 2005).

\section{Regulation of adrenomedullin expression}

Andrenomedullin expression is stimulated by cytokines and hypoxia and its promoter contains several putative hypoxia response elements (reviewed by Zudaire et al, 2003). Hypoxia induces AM expression and secretion in many cell types including carcinoma cell lines (endometrial, breast, neuroblastoma, colorectal) (reviewed by Zudaire et al, 2003) and endothelial cells (Nakayama et al, 1999; Nikitenko et al, 2003). Hypoxia is a frequent feature of the microenvironment in solid tumours and constitutes one of the driving forces of cancer growth and progression (Harris, 2002), and a role for AM as a promoter of these processes has been suggested (Oehler et al, 2001; Martinez et al, 2002; Ouafik et al, 2002). 


\section{Biodegradation of adrenomedullin and the role of adrenomedullin binding protein}

A specific AM binding protein (i.e., AMBP-1) has been described and characterised as human complement factor $\mathrm{H}$ (reviewed by Zudaire et al, 2003). Binding proteins can limit the transport of a peptide to the interstitial space and access to its specific receptors, modulate its biological activity, as well as protecting it from metabolic clearance by proteases and thereby prolonging the half-life in the circulation. This could explain why the growth promoting activity of AM is augmented in the presence of AMBP-1 (reviewed by Zudaire et al, 2003).

\section{Adrenomedullin receptors}

AM mediates its activities via heterodimeric receptors that are composed of a seven transmembrane (7TM) G-protein-coupled receptor (GPCR) calcitonin-receptor-like receptor (CRLR, now known as CL; Poyner et al, 2002), and a receptor activity modifying protein (RAMP) (McLatchie et al, 1998). The RAMP family comprises three members (RAMP1, RAMP2 and RAMP3) that share less than $30 \%$ sequence identity but a common topological organisation. They are small intrinsic membrane proteins with a large extracellular $N$-terminus ( $\sim 100$ amino acids), a single transmembrane domain, and a short intracellular domain (10 amino acids). Formation of heterodimers between RAMPs and CL is essential for proper cell surface targeting and to define ligandbinding selectivity of this GPCR (McLatchie et al, 1998). RAMP2 and RAMP3 promote the expression of AM receptors (termed AM1 and AM2, respectively), while coexpression of RAMP1 with CL leads to the formation of CGRP receptor (McLatchie et al, 1998; Poyner et al, 2002) (Figure 1). However, the mechanisms regulating CL and RAMPs expression remain poorly characterised.

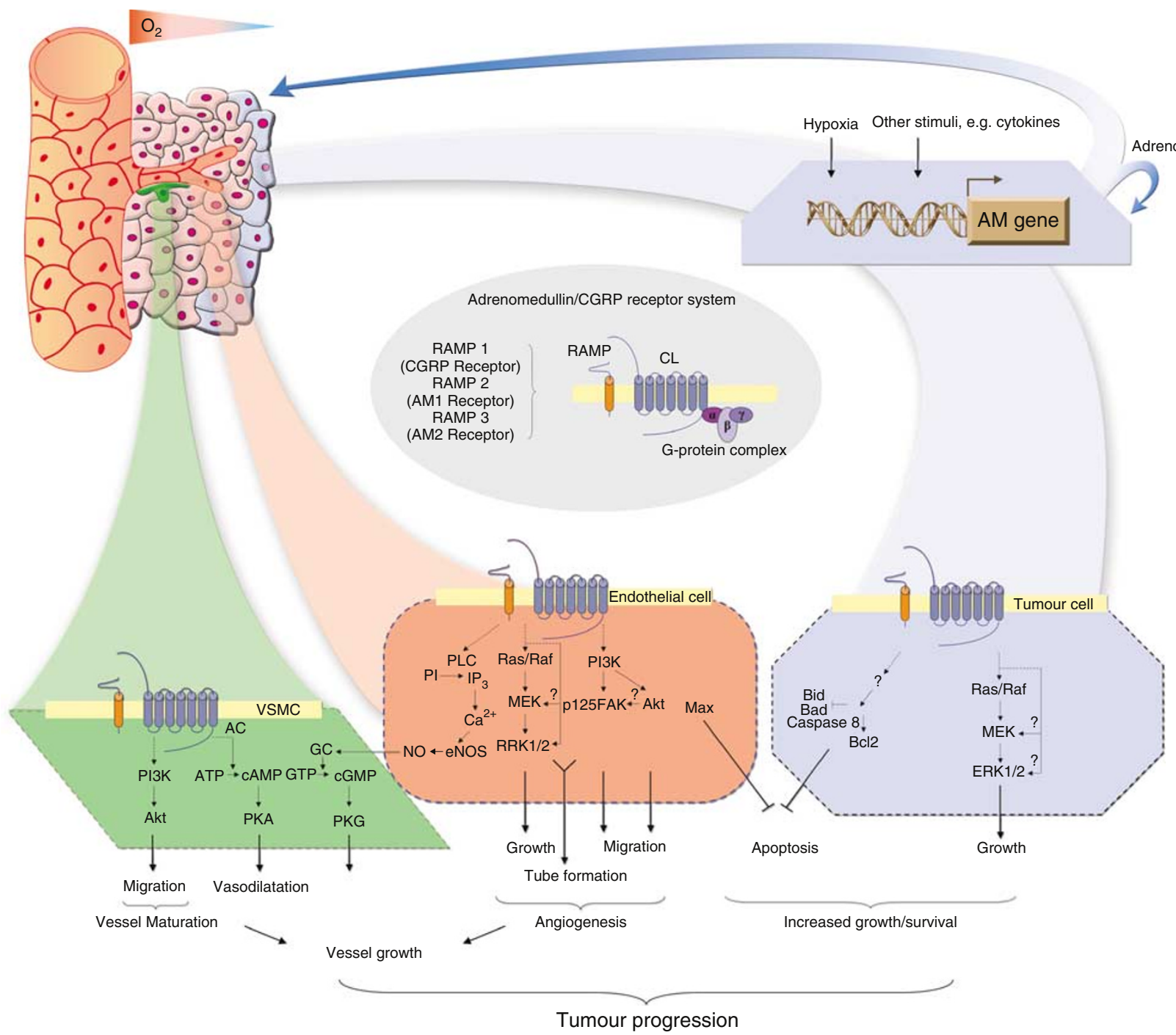

Figure I Role of adrenomedullin in tumour progression. The role of hypoxia and inflammatory cytokines in regulation of AM expression and secretion by tumour cells in vivo has been suggested. Adrenomedullin promotes formation of xenografted tumours by stimulation of autocrine growth and survival of tumour cells, and through paracrine effects on surrounding vessels. Possible intracellular signalling mechanisms underlying effects of AM in tumour microenvironment (in endothelial, vascular smooth muscle (VSMC) and tumour cells) suggest its potential role in tumorigenesis, resistance to chemotherapy and tumour progression. Based on McLatchie et al (1998), Shichiri et al (1999), Hinson et al (2000), Oehler et al (200 I), Martinez et al (2002), Poyner et al (2002), Kim et al (2003) and Iwase et al (2005). AC=adenylate cyclase; GC= guanylate cyclase; PKA= protein kinase $A$, PKG= protein kinase G, PLC = phospholipase C, MEK = mitogen-activated protein kinase kinase; ERK = extracellular signal-regulated kinase (also termed MAPK). 


\section{Adrenomedullin and cell signalling}

Adrenomedullin signal transduction differs between cell types, involving several pathways (Figure 1). Increasing evidence has shown that activation or disruption of AM signalling may contribute to pathologies including ischaemia-induced damage and neoplastic growth (reviewed in Hinson et al, 2000; reviewed in Nikitenko et al, 2002). It follows that the development of drugs modulating AM activity hold the potential for pro- or antiangiogenic therapies.

\section{ADRENOMEDULLIN AND CANCER}

Adrenomedullin has been shown to be involved in carcinogenesis and tumour progression by promoting tumour proliferation, angiogenesis and the inhibition of apoptosis. It is thought that inflammatory cytokines- and hypoxia-induced expression of AM by tumour cells drives these processes (Figure 1).

\section{Adrenomedullin and tumour cell proliferation}

Several AM-overexpressing human carcinoma cell lines exhibit enhanced growth in vitro and in vivo to a varying degree (Oehler et al, 2001; Martinez et al, 2002). Thus, the endometrial cancer cell line RL95.2 overexpressing AM showed a marked growth increase, but no increase was seen with Ishikawa-transfected endometrial carcinoma cells (Oehler et al, 2001). Adrenomedullin also maintains cell proliferation of breast tumour cell lines T47D in serum-free conditions (Martinez et al, 2002). Finally, an anti-AM antibody significantly decreased in vitro and in vivo growth of U87 glioblastoma cells that have a high level of endogenous AM (Ouafik et al, 2002).

\section{Adrenomedullin and angiogenesis}

A role for AM in physiological and pathological angiogenesis has been demonstrated using several in vitro, knockout mice and xenografted tumour models (Zhao et al, 1998; Hague et al, 2000; Nikitenko et al, 2000; Oehler et al, 2001; Fujita et al, 2002; Martinez et al, 2002; Kim et al, 2003) (Figure 2).

AM plays a role in the regulation of angiogenesis in the female reproductive tract (Nikitenko et al, 2000), during embryonic vascular development (Caron and Smithies, 2001; Shindo et al, 2001), and during vascular remodelling in response to ischaemia (Iimuro et al, 2004; Matsui et al, 2004). Thus, AM induces growth of human endometrial microvascular endothelial cells (Nikitenko et al, 2000). Studies using AM knockout mice suggest that AM is essential for vascular morphogenesis (Caron and Smithies, 2001; Shindo et al, 2001). Adrenomedullin also augments blood flow recovery and collateral capillary development in response to acute ischaemia (Abe et al, 2003).

Similarly, AM is considered to be angiogenic in tumours. For example, in leiomyomas, benign myometrial tumours, AM expression correlates with vascular density and the endothelial cell proliferation index (Hague et al, 2000). In xenografted tumour models utilising human endometrial, breast or pancreatic tumour cell lines, vascular density or directed growth of blood vessels was increased in AM-overexpressing transfectants (Oehler et al, 2001; Martinez et al, 2002; Ishikawa et al, 2003). Similar effects were observed after xenografting human glioblastoma cells, that were known to express high levels of endogenous AM (Ouafik et al, 2002). These observations have been confirmed in AM-heterozygous knockout mice, where decreased xenografted tumour growth and reduced neovascularisation in ischaemic conditions were observed (Iimuro et al, 2004).

A role for AM in vascular maturation has also been suggested (Iwase et al, 2005). AM stimulation of vascular smooth muscle cell (VSMC) migration and endothelium-independent vasodilatation may contribute to vascular maturation. Recent studies show that AM not only enhances the differentiation of bone marrow-derived mononuclear cells into endothelial cells but also facilitates formation of mature vessels that include VSMC (Iwase et al, 2005). In contrast, others demonstrated that endogenous AM could protect against pulmonary vascular remodelling induced by hypoxia or limit the arterial intimal hyperplasia induced by injury (Kawai et al, 2004; Matsui et al, 2004).

Finally, a role for PAMP in angiogenesis has also been suggested (Martinez et al, 2004b).

\section{Adrenomedullin and apoptosis}

Adrenomedullin inhibits apoptosis of both endothelial and tumour cells. For example, AM suppresses serum deprivation-induced apoptosis in rat endothelial cells (Kato et al, 1997). Stably transfected AM-overexpressing endometrial tumour cells show resistance to hypoxia-induced apoptosis via a bcl-2-mediated mechanism (Oehler et al, 2002). Furthermore, AM-overexpressing breast carcinoma cells show lower levels of proapoptotic factors such as Bax, Bid and caspase 8 , concomitant with higher resistance to apoptosis (after serum deprivation), than cells transfected with the empty vector (Martinez et al, 2002).

\section{ADRENOMEDULLIN RECEPTORS AND SIGNALLING IN TUMOUR BIOLOGY}

Currently CL is considered to be the main receptor mediating AM effects (McLatchie et al, 1998; Poyner et al, 2002). In normal tissues $\mathrm{CL}$ is predominantly expressed in microvascular endothelial cells, supporting the view that this GPCR is potentially a major regulator of the effects of AM on vasculature (Nikitenko et al, 2003). Calcitonin-receptor-like receptor gene transcription is upregulated in endothelial cells in hypoxia. Simultaneous transcriptional upregulation of CL and it ligand AM in endothelial cells might play a significant role in vascular responses to hypoxia and ischaemia by creating a survival loop. Calcitonin-receptor-like receptor is also upregulated in some human tumours (Nikitenko et al, 2003).

In vascular endothelial cells, activation of phosphatydylinositol $3^{\prime}$ kinase (PI3K/Akt), mitogen-activated protein kinase (MAPK) and focal adhesion kinase (p125FAK) plays a role in AM-induced angiogenesis (Figure 1). Thus, AM-stimulated migration of human umbilical vein endothelial cells (HUVEC) is inhibited by PI3K- or MAPK-inhibitors (Kim et al, 2003). Nitric oxide (NO) upregulation by AM has been implicated in endothelium-dependent vasodilatation (reviewed in Hinson et al, 2000). Adrenomedullin reduces endothelial apoptosis via a c-AMP-independent mechanism, and by upregulation of transcription factor Max (Kato et al, 1997; Shichiri et al, 1999).

The mitogenic activity of AM on VSMC is mediated via a cAMPdependent pathway and/or a MAPK (reviewed by Hinson et al, 2000). Endothelium-independent vasodilatory effects of AM are mediated via a cAMP-dependent mechanism in VSMC (Figure 1). Adrenomedullin-stimulated VSMC migration is inhibited by wortmannin, a PI3K inhibitor, and it has been suggested that activation of PI3K/Akt by the peptide in vivo contributes to recruitment of VSMC to a newly formed capillary network (Iwase et al, 2005). Stimulation of vascular maturation by a direct effect of AM on VSMC is in sharp contrast to VEGF that stimulates new vessel formation but not maturation. Whether AM and VEGF act synergistically or independently remains to be elucidated. Two recent studies have shown that AM enhances vascular endothelial growth factor (VEGF)-induced capillary formation by HUVEC in vitro, but there is disagreement on the ability of AM to stimulate VEGF production in these cells (Fernandez-Sauze et al, 2004; Iimuro et al, 2004). 
A
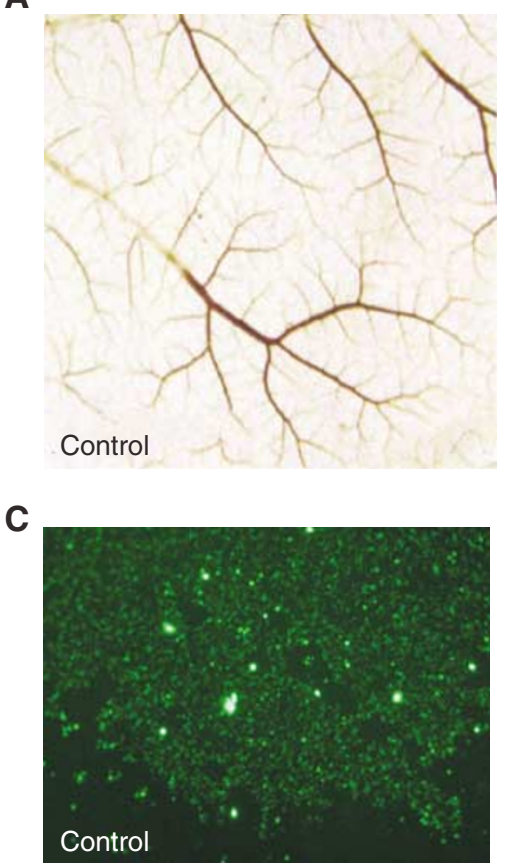

D

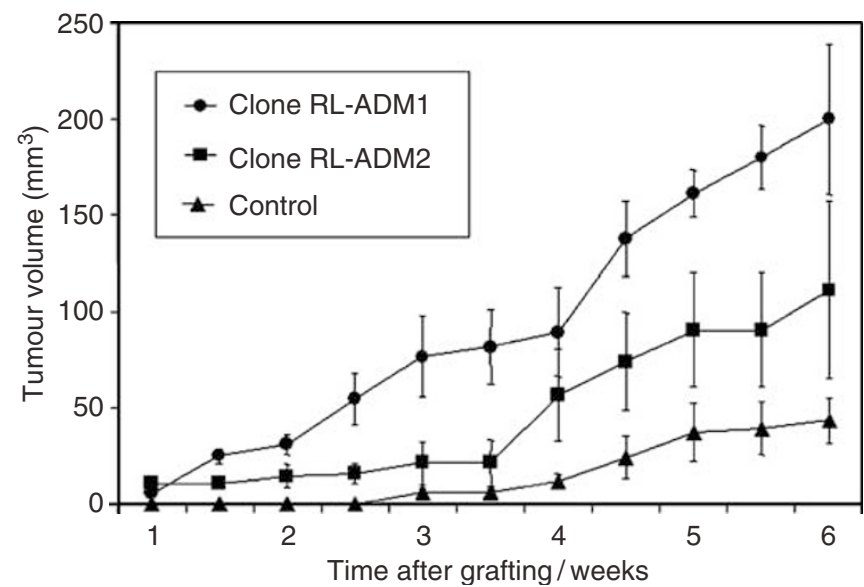

B
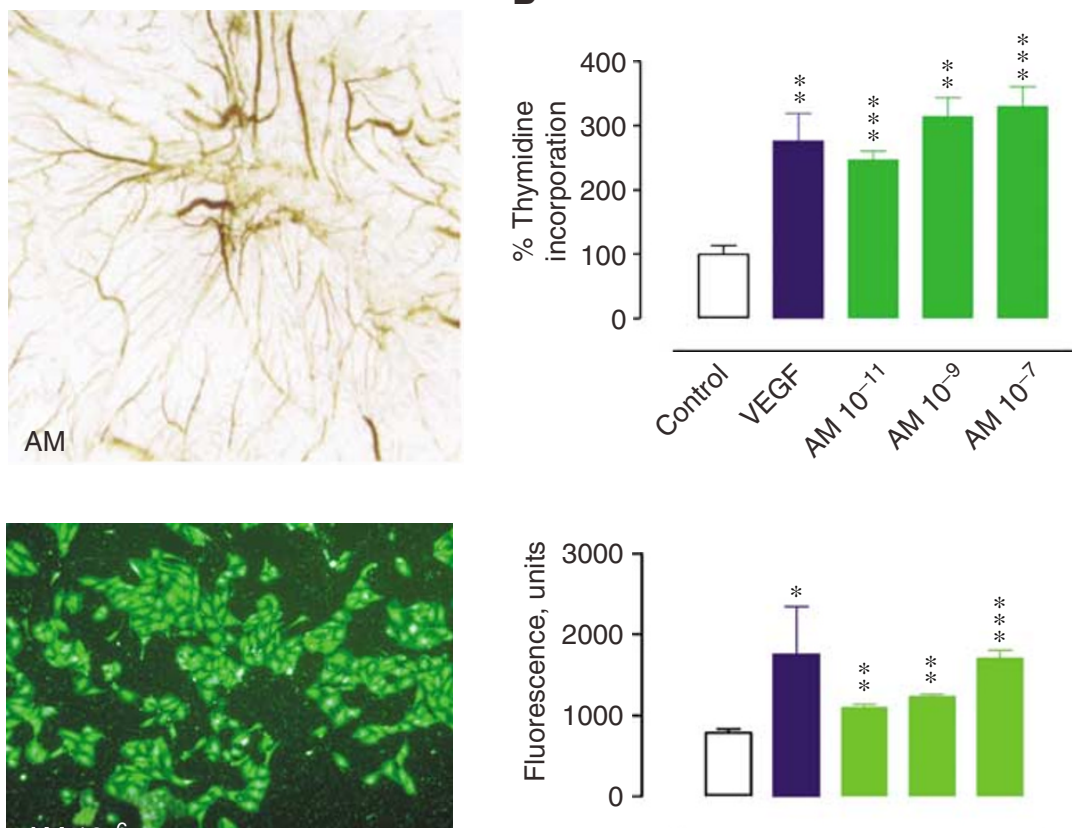

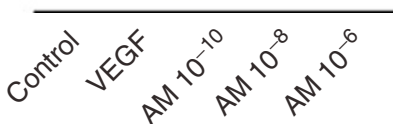

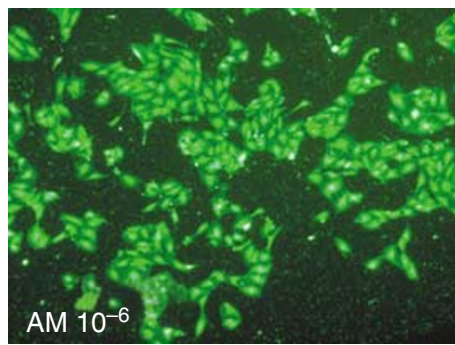

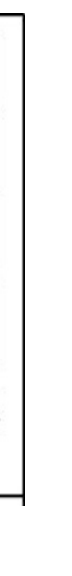

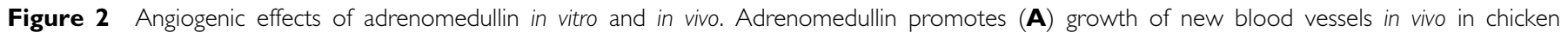

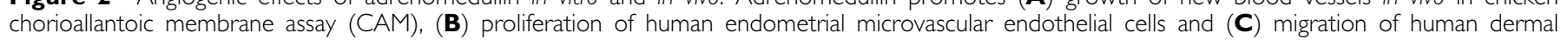

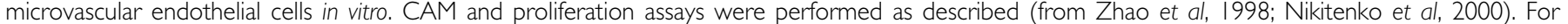

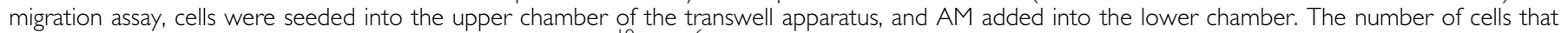

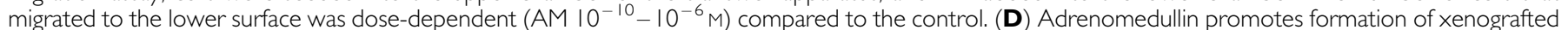

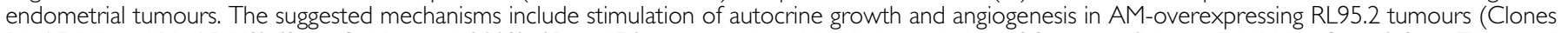

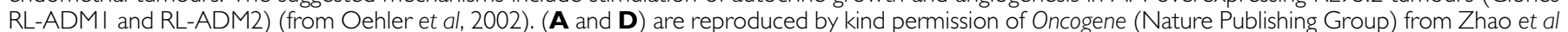
(1998) and Oehler et al (2002). Each point represents the mean \pm s.e.m. (* $P<0.05$; $* * P<0.01$; $* * * P<0.001$; as compared to controls).

Transfected tumour cells overexpressing AM have higher levels of oncogenic proteins such as Ras, Raf, PKC and MAPKp49 and incorporate more bromodeoxiuridine (after serum deprivation) compared to controls (Martinez et al, 2002) (Figure 1). Adrenomedullin-mediated upregulation of antiapoptotic factors in hypoxia or downregulation of pro-apoptotic factors contributes to tumour cell survival (Oehler et al, 2001; Martinez et al, 2002). Further, AMBP-1 enhances AM-mediated growth in breast cancer cell lines and has been recently implicated in a mechanism leading to tumour cell survival by resistance to complement-mediated lysis (reviewed in Zudaire et al, 2003). However, the role of AMBP-1 in protection of tumour cells from apoptosis is unknown and further studies are needed.

\section{ADRENOMEDULLIN AND TUMOUR THERAPY}

Several strategies have been proposed to inhibit AM-induced angiogenesis and tumour cell growth and survival. Among these are approaches that aim to: (1) modulate AM expression (AM mRNA rybozyme), (2) alter AM binding to its receptor (anti-AM blocking antibodies, receptor antagonists, truncated peptides, e.g., $\mathrm{AM}_{22-52}$ and $\mathrm{CGRP}_{8-37}$, and small nonpeptide molecules), or (3) inhibit specific AM-induced intracellular signalling pathways (e.g. using anti-CL or anti-RAMPs blocking antibodies, inhibitors of PI3K/Akt or MAPK pathways and other angiostatic molecules, e.g., vinblastine) (Table 1). Several such strategies have successfully attenuated AM-induced signalling and inhibited endothelial cell growth and migration, or 
Table I Specific and nonspecific modulators of adrenomedullin-induced effects

\begin{tabular}{|c|c|c|c|c|c|}
\hline Target & Drug & $\begin{array}{l}\text { Mode of action/ } \\
\text { biological activity }\end{array}$ & $\begin{array}{l}\text { Side-effects/ } \\
\text { disadvantages }\end{array}$ & $\begin{array}{l}\text { Antiangiogenic } \\
\text { potential }\end{array}$ & Reference \\
\hline \multicolumn{6}{|c|}{ Specific modulators of AM-induced effects } \\
\hline \multirow[t]{5}{*}{ Ligand (adrenomedullin) } & AM mRNA rybozyme & AM mRNA degradation & $\begin{array}{l}\text { Lack of reliable targeted } \\
\text { delivery }\end{array}$ & Not tested & $\begin{array}{l}\text { Taylor and Samson } \\
\text { (2002) }\end{array}$ \\
\hline & AMBP-I (binding protein) & $\begin{array}{l}\text { Affinity to receptor is } \\
\text { unaltered } \\
\text { Protection of peptide from } \\
\text { degradation by proteases }\end{array}$ & Not tested & Not tested & $\begin{array}{l}\text { Reviewed by Zudaire } \\
\text { et al (2003) }\end{array}$ \\
\hline & Anti-AM blocking antibody & Inhibition of AM activity & Not tested & $\begin{array}{l}\text { Decreased mean } \\
\text { vessel area in tumour } \\
\text { xenografts }\end{array}$ & Ouafik et al (2002) \\
\hline & $\begin{array}{l}\text { Positive nonpeptidic } \\
\text { regulators }\end{array}$ & Binding to $A M$ & Vasodilation in vivo & Not tested & $\begin{array}{l}\text { Martinez et al } \\
(2004 a, b)\end{array}$ \\
\hline & $\begin{array}{l}\text { Negative nonpeptidic } \\
\text { regulators }\end{array}$ & Binding to AM & Vasoconstriction & Not tested & $\begin{array}{l}\text { Martinez et al } \\
(2004 a, b)\end{array}$ \\
\hline \multirow[t]{4}{*}{ Receptor } & Fragmentary peptides & & & & \\
\hline & AM22-52 (receptor & Competition with ligand & Short half-life & Not tested & Poyner et al (2002) \\
\hline & $\begin{array}{l}\text { antagonist) } \\
\text { CGRP8-37 (receptor } \\
\text { antagonist) }\end{array}$ & for binding to the receptor & Short half-life & Not tested & Poyner et al (2002) \\
\hline & $\begin{array}{l}\text { Anti-CL blocking antibody } \\
\text { Anti-RAMPs blocking } \\
\text { antibodies }\end{array}$ & $\begin{array}{l}\text { Direct interaction with } \\
\text { receptor has been } \\
\text { suggested }\end{array}$ & $\begin{array}{l}\text { Not tested } \\
\text { Not tested }\end{array}$ & $\begin{array}{l}\text { Inhibit HUVEC migration } \\
\text { and capillary tube } \\
\text { formation in vitro }\end{array}$ & $\begin{array}{l}\text { Fernandez-Sauze } \\
\text { et al (2004) }\end{array}$ \\
\hline \multicolumn{6}{|c|}{ Nonspecific modulators of AM-induced effects } \\
\hline $\begin{array}{l}\text { Signalling cascades } \\
\text { (secondary messengers) }\end{array}$ & $\begin{array}{l}\text { Wortmannin (PI3K } \\
\text { inhibitor) PD98059 } \\
\text { (MAPK inhibitors) }\end{array}$ & $\begin{array}{l}\text { Inhibition of ligand-induced } \\
\text { phospohorylation of } \\
\text { secondary messengers/ } \\
\text { kinases }\end{array}$ & $\begin{array}{l}\text { Nonspecific } \\
\text { Nonspecific }\end{array}$ & $\begin{array}{l}\text { Prevent angiogenesis } \\
\text { in vitro and in vivo }\end{array}$ & $\begin{array}{l}\text { Kim et al (2003) } \\
\text { Kim et al (2003) }\end{array}$ \\
\hline Unknown & Vinblastine & $\begin{array}{l}\text { Interaction with } \\
\text { cytoskeleton }\end{array}$ & Nonspecific & $\begin{array}{l}\text { Interruption of AM-induced } \\
\text { capillary-like tube formation }\end{array}$ & Ribatti et al (2003) \\
\hline
\end{tabular}

increased tumour cell apoptosis. Studies in knockout mice have demonstrated that loss of AM results in elevated blood pressure (Shindo et al, 2001), which could be a problem in blocking therapies.

\section{CLINICAL RELEVANCE OF ADRENOMEDULLIN AND ITS RECEPTORS IN CANCER AND FUTURE TRANSLATIONAL RESEARCH}

Although the role of AM has been studied using in vitro and murine xenografted tumour models, studies in man have been limited to use of cancer cell lines and a few tumours.

Currently, immunohistochemistry and RT - PCR have been the first choice with which to study AM expression and distribution in human tumour tissues, but there is a paucity of quantitative data. There is also little data concerning which cells express the messenger RNA within tumours (Rocchi et al, 2001). A few studies have been performed to measure peptide levels in blood or tumour tissues from sufficient number of patients to enable statistical analysis (Satoh et al, 1995; Oehler et al, 2003). For example, it has been shown that the plasma AM level in breast cancer patients correlates with primary tumour size and lymph node metastasis $(P=0.002)$, as measured by radioimmunoassay (Oehler et al, 2003). However, despite the fact that plasma AM may be an independent predictor of lymph node metastasis, it was concluded that it is unlikely to be a useful tumour marker for the detection of breast cancer.

The correlation of AM mRNA expression with tumour stage has been demonstrated only for human glioblastomas (Ouafik et al, 2002). Its correlation with vascular density has been demonstrated in renal tumours and uterine leiomyoma (Hague et al, 2000; Fujita et al, 2002). However, the small patient number used in the first two studies (with a maximum of six and 12 samples per group, respectively) limits reliable conclusions. Studies by Hague et al (2000) did not examine correlations within leiomyoma-bearing uteri, making it difficult to assess the potential of anti-AM strategies and their possible effects on surrounding myometrium.

Finally, no studies have yet used quantitative methods to assess the mRNA and protein expression levels for components of the $A M$ receptor system (CL and RAMPs). Information on the distribution, regulation and function of endogenous AM receptors is poor, and data on their role in human tumour biology is not available. CL mRNA might be upregulated in some tumour types (Nikitenko et al, 2003), but little information is available on protein expression, receptor distribution, or concerning CLmediated signalling pathways involved in human tumours. RAMPs 2 and 3 mRNAs have also been found in some tumour types, but no studies have characterised the expression of functional endogenous AM receptors and their role in tumorigenesis. Thus there is still much to be learned about their role in human cancer especially in regards to translational research (Liang, 2003).

\section{CONCLUDING REMARKS, UNANSWERED QUESTIONS AND FUTURE DIRECTIONS}

\section{Validation of adrenomedullin as a tumour expressed gene}

Several studies have shown that expression of AM by tumour models enhances tumour growth and angiogenesis, whereas blocking AM antibodies have the reverse effect. While these observations point to 
a potential role for $\mathrm{AM}$ and its receptors in tumour angiogenesis, their role in human cancer is as yet poorly defined. There exists an urgent need for a greater assessment of AM as a novel tumour marker. In the first place this requires a knowledge of the expression at the mRNA and protein level of AM and CL in human normal and tumour tissues. Ideally, this would involve correlation of expression levels in patients with clinico-pathological data. Expression studies have shown AM (like VEGF) to be widely expressed in normal adult tissue. Expression is greatest in the placenta and endometrium that are undergoing active angiogenesis, but was also significant in the adrenal medulla, lung and kidney (Kitamura et al, 1993b). A more detailed analysis nevertheless suggests that in some cases tumour expression is greater than that in corresponding normal tissue, for example, kidney where it is many fold higher (L. Nikitenko, unpublished work). Several in vitro studies have demonstrated that hypoxia upregulates AM expression in tumour cells and this needs to be validated in vivo by, for example, in situ hybridisation (Rocchi et al, 2001). The accurate determination of AM peptide in tissues is far from straightforward. There is no readily available ELISA for AM leaving radioimmunoassay as the most sensitive assay (Satoh et al, 1995; Oehler et al, 2003). Interpretation of the results is confounded by the existence of adrenomedullin binding protein-1 (AMBP-1) and the question of how much AM is bound to AMBP-1 or free (reviewed in Zudaire et al, 2003).

\section{Adrenomedullin as a therapeutic target}

There is a need to identify the tumour types where expression of $\mathrm{AM}$ and its receptors correlate with, for example, vascularisation, prognosis and resistance to chemotherapy. This would single out tumours in which AM plays a role and where anti-AM therapeutic intervention may have potential. That antibodies to AM reduce tumour growth in animal models was a significant observation reminiscent of similar observations with anti-VEGF antibodies a decade earlier. The VEGF studies eventually led to the development of the anti-VEGF drug 'Avastin' and its efficacy in the treatment of advanced metastatic colon cancer (Hurwitz et al, 2004). Nevertheless, Avastin-treated tumours eventually re-grow despite continued treatment, and it is potent angiogenic factors such as AM that are likely to be responsible for the breakthrough angiogenesis. One consideration is potential side effects of AM-blocking antibody, since loss of AM results in elevated blood pressure as demonstrated by studies in AM knockout mice (Shindo et al, 2001). A detailed knowledge of the interaction of AM with its receptors, and mechanisms of their expression and function will provide insights that are essential for the future development of chemical compounds and antibodies that can modulate the activity of endogenous AM receptors. Such drugs may have potential for antitumour therapy.

\section{ACKNOWLEDGEMENTS}

This work was supported in part by The Wellcome Trust (LLN, MCPR), Medical Research Fund (University of Oxford, UK) (LLN) and Cancer Research UK (RB). We are grateful to Robin RobertsGant for assistance with formatting figures.

\section{REFERENCES}

Abe M, Sata M, Nishimatsu H, Nagata D, Suzuki E, Terauchi Y, Kadowaki T, Minamino N, Kangawa K, Matsuo H, Hirata Y, Nagai R (2003) Adrenomedullin augments collateral development in response to acute ischemia. Biochem Biophys Res Commun 306(1): 10-15

Caron KM, Smithies O (2001) Extreme hydrops fetalis and cardiovascular abnormalities in mice lacking a functional adrenomedullin gene. Proc Natl Acad Sci USA 98: 615-619

Fernandez-Sauze S, Delfino C, Mabrouk K, Dussert C, Chinot O, Martin PM, Grisoli F, Ouafik L, Boudouresque F (2004) Effects of adrenomedullin on endothelial cells in the multistep process of angiogenesis: involvement of CRLR/RAMP2 and CRLR/RAMP3 receptors. Int J Cancer 108(6): $797-804$

Fujita Y, Mimata H, Nasu N, Nomura T, Nomura Y, Nakagawa M (2002) Involvement of adrenomedullin induced by hypoxia in angiogenesis in human renal cell carcinoma. Int J Urol 9(6): 285-295

Hague S, Zhang L, Oehler MK, Manek S, MacKenzie IZ, Bicknell R, Rees MC (2000) Expression of the hypoxically regulated angiogenic factor adrenomedullin correlates with uterine leiomyoma vascular density. Clin Cancer Res 3: $2808-2814$

Harris AL (2002) Hypoxia - a key regulatory factor in tumour growth. Nat Rev Cancer 2(1): 38-47

Hinson JP, Kapas S, Smith DM (2000) Adrenomedullin, a multifunctional regulatory peptide. Endocr Rev 21: $138-167$

Hippenstiel S, Witzenrath M, Schmeck B, Hocke A, Krisp M, Krull M, Seybold J, Seeger W, Rascher W, Schutte H, Suttorp N (2002) Adrenomedullin reduces endothelial hyperpermeability. Circ Res 91(7): $18-25$

Hurwitz H, Fehrenbacher L, Novotny W, Cartwright T, Hainsworth J, Heim W, Berlin J, Baron A, Griffing S, Holmgren E, Ferrara N, Fyfe G, Rogers B, Ross R, Kabbinavar F (2004) Bevacizumab plus irinotecan, fluorouracil, and leucovorin for metastatic colorectal cancer. $N$ Engl J Med 350: $2335-2342$

Iimuro S, Shindo T, Moriyama N, Amaki T, Niu P, Takeda N, Iwata H, Zhang Y, Ebihara A, Nagai R (2004) Angiogenic effects of adrenomedullin in ischemia and tumor growth. Circ Res 95(4): 415-423

Ishikawa T, Chen J, Wang J, Okada F, Sugiyama T, Kobayashi T, Shindo M, Higashino F, Katoh H, Asaka M, Kondo T, Hosokawa M, Kobayashi M
(2003) Adrenomedullin antagonist suppresses in vivo growth of human pancreatic cancer cells in SCID mice by suppressing angiogenesis. Oncogene 22(8): $1238-1242$

Iwase $\mathrm{T}$, Nagaya $\mathrm{N}$, Fujii $\mathrm{T}$, Itoh $\mathrm{T}$, Ishibashi-Ueda $\mathrm{H}$, Yamagishi $\mathrm{M}$, Miyatake K, Matsumoto T, Kitamura S, Kangawa K (2005) Adrenomedullin enhances angiogenic potency of bone marrow transplantation in a rat model of hindlimb ischemia. Circulation 111(3): 356-362

Kato H, Shichiri M, Marumo F, Hirata Y (1997) Adrenomedullin as an autocrine/paracrine apoptosis survival factor for rat endothelial cells. Endocrinology 138(6): 2615-2620

Kawai J, Ando K, Tojo A, Shimosawa T, Takahashi K, Onozato ML, Yamasaki M, Ogita T, Nakaoka T, Fujita T (2004) Endogenous adrenomedullin protects against vascular response to injury in mice. Circulation 109(9): 1147-1153

Kim W, Moon SO, Sung MJ, Kim SH, Lee S, So JN, Park SK (2003) Angiogenic role of adrenomedullin through activation of Akt, mitogenactivated protein kinase, and focal adhesion kinase in endothelial cells. FASEB J 17: $1937-1939$

Kitamura K, Kangawa K, Kawamoto M, Ichiki Y, Nakamura S, Matsuo H, Eto T (1993a) Adrenomedullin: a novel hypotensive peptide isolated from human pheochromocytoma. Biochem Biophys Res Commun 192(2): $553-560$

Kitamura K, Sakata J, Kangawa K, Kojima M, Matsuo H, Eto T (1993b) Cloning and characterization of cDNA encoding a precursor for human adrenomedullin. Biochem Biophys Res Commun 194(2): 720-725

Liang $\mathrm{MH}$ (2003) Translational research: getting the word and the meaning right. Arthritis Rheum 49(5): 720-721, review

Martinez A, Julian M, Bregonzio C, Notari L, Moody TW, Cuttitta F (2004a) Identification of vasoactive nonpeptidic positive and negative modulators of adrenomedullin using a neutralizing antibody-based screening strategy. Endocrinology 145(8): 3858 - 3865

Martinez A, Vos M, Guedez L, Kaur G, Chen Z, Garayoa M, Pio R, Moody T, Stetler-Stevenson WG, Kleinman HK, Cuttitta F (2002) The effects of adrenomedullin overexpression in breast tumor cells. J Natl Cancer Inst 94(16): $1226-1237$

Martinez A, Zudaire E, Portal-Nunez S, Guedez L, Libutti SK, StetlerStevenson WG, Cuttitta F (2004b) Proadrenomedullin NH2-terminal 20 
peptide is a potent angiogenic factor, and its inhibition results in reduction of tumor growth. Cancer Res 64(18): 6489-6494

Matsui H, Shimosawa T, Itakura K, Guanqun X, Ando K, Fujita T (2004) Adrenomedullin can protect against pulmonary vascular remodeling induced by hypoxia. Circulation 109(18): 2246-2251

McLatchie LM, Fraser NJ, Main MJ, Wise A, Brown J, Thompson N, Solari R, Lee MG, Foord SM (1998) RAMPs regulate the transport and ligand specificity of the calcitonin-receptor-like receptor. Nature 393: 333-339

Nakayama M, Takahashi K, Murakami O, Shirato K, Shibahara S (1999) Induction of adrenomedullin by hypoxia in cultured human coronary artery endothelial cells. Peptides 20(6): 769-772

Nikitenko LL, MacKenzie IZ, Rees MCP, Bicknell R (2000) Adrenomedullin is an autocrine regulator of endothelial growth in human endometrium. Mol Hum Reprod 6(9): $811-819$

Nikitenko LL, Smith DM, Bicknell R, Rees MCP (2003) Transcriptional regulation of the CRLR gene in human microvascular endothelial cells by hypoxia. FASEB J 17(11): 1499-1501. Full length article is Available at: http://www.fasebj.org/cgi/reprint/02-0993fjev1.pdf

Nikitenko LL, Smith DM, Hague S, Bicknell R, Rees MCP (2002) Adrenomedullin and the microvasculature. Trends Pharm Sci 23(3): $101-103$

Oehler MK, Fischer DC, Orlowska-Volk M, Herrle F, Kieback DG, Rees MC, Bicknell R (2003) Tissue and plasma expression of the angiogenic peptide adrenomedullin in breast cancer. Br J Cancer 89(10): 1927 - 1933

Oehler MK, Hague S, Rees MC, Bicknell R (2002) Adrenomedullin promotes formation of xenografted endometrial tumors by stimulation of autocrine growth and angiogenesis. Oncogene 21: 2815-2821

Oehler MK, Norbury C, Hague S, Rees MC, Bicknell R (2001) Adrenomedullin inhibits hypoxic cell death by upregulation of Bcl-2 in endometrial cancer cells: a possible promotion mechanism for tumour growth. Oncogene 20: 2937-2945

Ouafik L, Sauze S, Boudouresque F, Chinot O, Delfino C, Fina F, Vuaroqueaux V, Dussert C, Palmari J, Dufour H, Grisoli F, Casellas P, Brunner N, Martin PM (2002) Neutralization of adrenomedullin inhibits the growth of human glioblastoma cell lines in vitro and suppresses tumor xenograft growth in vivo. Am J Pathol 160(4): 1279-1292
Poyner DR, Sexton PM, Marshall I, Smith DM, Quirion R, Born W, Muff R, Fischer JA, Foord SM (2002) International Union of Pharmacology. XXXII. The mammalian calcitonin gene-related peptides, adrenomedullin, amylin, and calcitonin receptors. Pharmacol Rev 54: $233-246$

Ribatti D, Guidolin D, Conconi MT, Nico B, Baiguera S, Parnigotto PP, Vacca A, Nussdorfer GG (2003) Vinblastine inhibits the angiogenic response induced by adrenomedullin in vitro and in vivo. Oncogene 22(41): $6458-6461$

Rocchi P, Boudouresque F, Zamora AJ, Muracciole X, Lechevallier E, Martin PM, Ouafik L (2001) Expression of adrenomedullin and peptide amidation activity in human prostate cancer and in human prostate cancer cell lines. Cancer Res 61(3): 1196-1206

Satoh F, Takahashi K, Murakami O, Totsune K, Sone M, Ohneda M, Abe K, Miura Y, Hayashi Y, Sasano H, Mouri T (1995) Adrenomedullin in human brain, adrenal glands and tumor tissues of pheochromocytoma, ganglioneuroblastoma and neuroblastoma. J Clin Endocrinol Metab 80(5): $1750-1752$

Shichiri M, Kato H, Doi M, Marumo F, Hirata Y (1999) Induction of max by adrenomedullin and calcitonin gene-related peptide antagonizes endothelial apoptosis. Mol Endocrinol 13: 1353 - 1363

Shindo T, Kurihara Y, Nishimatsu H, Moriyama N, Kakoki M, Wang Y, Imai Y, Ebihara A, Kuwaki T, Ju KH, Minamino N, Kangawa K, Ishikawa T, Fukuda M, Akimoto Y, Kawakami H, Imai T, Morita H, Yazaki Y, Nagai R, Hirata Y, Kurihara H (2001) Vascular abnormalities and elevated blood pressure in mice lacking adrenomedullin gene. Circulation 104: $1964-1971$

Taylor MM, Samson WK (2002) Ribozyme compromise of adrenomedullin mRNA reveals a physiological role in the regulation of water intake. $A m \mathrm{~J}$ Physiol Regul Integr Comp Physiol 282(6): R1739-45

Zhao Y, Hague S, Manek S, Zhang L, Bicknell R, Rees MCP (1998) PCR display identifies tamoxifen induction of the novel angiogenic factor adrenomedullin by a non estrogenic mechanism in the human endometrium. Oncogene 16: 409-415

Zudaire E, Martinez A, Cuttitta F (2003) Adrenomedullin and cancer. Regul Pept 112: $175-183$ 